\title{
Intellectual capital of the MSMES in the area of influence. Universidad Tecnológica de Tula Tepeji
}

\section{Capital intelectual de las MSMES de la zona de influencia. Universidad Tecnológica de Tula Tepeji}

AGUILAR-MAYA, Laura*†, GARCÍA-GUERRERO, Martha Gabrielá, LÓPEZ-LAGUNA, Ana Bertha", ÁVILA-HERNÁNDEZ, José César" and HERNÁNDEZ-CHÁVEZ, Araceli"

'Universidad Tecnológica de Tula-Tepeji. Avenida Universidad Tecnológica, El Carmen, 42830 Hgo.
„Universidad Tecnológica de Guadalajara. Colonia, Luis J. Jiménez 577, lo. de Mayo, 44979 Guadalajara, Jal.
'Universidad Tecnológica de Bahía de Banderas. Blvd. Nuevo Vallarta No. 65 Pte, 63732 Nuevo Vallarta, Nay.

ID $1^{\text {st }}$ Author: Laura, Aguilar-Maya

ID $1^{\text {st }}$ Coauthor: Martha Gabriela, García-Guerrero

ID $2^{\text {nd }}$ Coauthor: Ana Bertha, López-Laguna

ID $3^{\text {rd }}$ Coauthor: José César, Ávila-Hernández.

ID $4^{\text {th }}$ Coauthor: Araceli, Hernández-Chávez

DOI: $10.35429 / J G E .2019 .5 .3 .14 .22$

Received July 24, 2019; Accepted December 27, 2019

\begin{abstract}
Mexico's Academic Synergy Network-MyPyMES developed a project called "The Intellectual Capital of mSMEs of the area of influence of the Technological Universities" to carry out an analysis of the indicators that make up the Intellectual Capital: active intangible value-added and competitive advantages for business development; was done to determine the value of the Skandia Browser Model approaches with a web-mobile application. The type of research was exploratory, cross-cutting and with a mixed approach, the survey technique was used by applying a questionnaire to 32 MSMEs of the Tula-Tepeji area. As a result, it was found that most do not have financial data or administrative procedures to determine the five approaches of Skandia Browser, the most important thing for companies is to sell; however, they do not conduct market research, very few are led by a professional who applies strategic planning, or have a definite mission or vision; Managers also do not know what Intellectual Capital is, do not attach importance to the development and training of staff, do not use ICT's as a management tool, do not evaluate processes or implement continuous improvement. It was concluded that the MSMEs in the buffer area present an area of opportunity to develop their intellectual capital, therefore higher education institutions must assist in the training of entrepreneurs and design a model to implement appropriate methodologies and procedures that promote intellectual capital.
\end{abstract}

Intellectual Capital, Diagnostics, Skandia Browser

\section{Resumen}

La Red Sinergia Académica-MyPyMES de México desarrolló un proyecto denominado "El Capital Intelectual de las MSMEs de la zona de influencia de las Universidades Tecnológicas" para realizar un análisis de los indicadores que conforman el Capital Intelectual: activo intangible que genera valor agregado y ventajas competitivas para el desarrollo de las empresas; se realizó para determinar el valor de los enfoques del Modelo Navegador Skandia con una aplicación Web-móvil. El tipo de investigación fue exploratoria, transversal y con enfoque mixto, se utilizó la técnica de encuesta aplicando un cuestionario a 32 MSMEs de la zona Tula-Tepeji. Como resultado se encontró que la mayoría no cuentan con datos financieros o procedimientos administrativos para determinar los cinco enfoques del Navegador Skandia, lo más importante para las empresas es vender; sin embargo, no realizan estudios de mercado, muy pocas están dirigidas por un profesional que aplique planeación estratégica, o tienen una misión o visión definida; asimismo, los directivos desconocen qué es el Capital Intelectual, no dan importancia al desarrollo y capacitación del personal, no utilizan las TIC's como herramienta gerencial, no evalúan procesos ni aplican la mejora continua. Se concluyó que las MSMEs de la zona de influencia presentan un área de oportunidad para desarrollar su capital intelectual, por lo tanto, las instituciones de educación superior deben de coadyuvar a la capacitación de los empresarios y diseñar un modelo para implementar metodologías y procedimientos adecuados que fomenten el Capital Intelectual.

Capital intelectual, Diagnóstico, Navegador Skandia

Citation: AGUILAR-MAYA, Laura, GARCÍA-GUERRERO, Martha Gabriela, LÓPEZ-LAGUNA, Ana Bertha, ÁVILAHERNÁNDEZ, José César and HERNÁNDEZ-CHÁVEZ, Araceli. Intellectual capital of the MSMES in the area of influence. Universidad Tecnológica de Tula Tepeji. RINOE Journal-General Economics. 2019. 3-5: 14-22.

\footnotetext{
* Correspondence to Author (email: 1.aguilar.maya@gmail.com)
}

$\dagger$ Researcher contributing first author. 


\section{Introduction}

The latest demographic study of INEGI (2016) establishes that the life expectancy of businesses in Mexico, after being created, is 7.8 years, based on the national average. Various studies have shown that the majority of these companies die from very similar problems, the owners argue that the reasons for the failure are poor official, financial support and high tax rates; For business analysts, the causes are mainly the lack of management capacity of the owners (Soriano, 2005). The Ministry of Economy (2014) argues that the MSMEs constitute the backbone of the national economy because of its high impact on job creation and national production. The National Institute of Statistics and Geography (INEGI) reported in its new National Statistical Directory of Economic Units 2015, that in Mexico there are a total of 4 million 926 thousand companies, of which $99.8 \%$ are MSMEs that generate $52 \%$ of the Gross Domestic Product (GDP) and $72 \%$ of the country's employment.

Expert business advisors conclude that the success of MSMEs is mainly due to the fact that they design strategies, have a customer focus, carry out constant studies of their market, occupy work tools, use technology and develop their human capital, hence the importance of the management of the intangible elements of the company that in general terms constitute Intellectual Capital and that represents a key element to obtain competitive advantages; So its identification and investment must be a primary objective, since it influences the real and total value of the company.

One of the policies of the Technological Innovation Fund of the National Technology Council (CONACYT) contemplates promoting a knowledge-based economy, through support for innovation projects, aimed at developing and / or strengthening resources with scientific and technological infrastructure human, infrastructure and machinery and, intellectual property protection. These funds and agreements provide MSMEs with the means and tools for knowledge management through Intellectual Capital, so it is necessary to develop a culture that encourages senior management, the need for an analysis of their Intellectual Capital, which will support its strategic approach, competitiveness, productivity and financial stability.
Therefore, it is important to implement actions that improve the economic environment and directly support the MSMEs, with the purpose of creating the conditions that contribute to its establishment, growth and consolidation. In order to achieve these conditions, in addition to making a diagnosis of Intellectual Capital, it is required that the MSMEs undertake to meet their organizational objectives and implement actions aimed at transforming their administrative, operational and structural processes.

After the previous considerations and in attention to the figures related to the failure and non-development of the MSMEs, the interest of generating an analysis of Intellectual Capital in the area of influence of the Technological Universities of Tula-Tepeji, Jalisco and Bahía de Banderas was born to promote its application and contribute to the strengthening of Human, Structural and Relational Capital through the Academic Bodies (CA's) of Administrative, Accounting and Fiscal Models; Information Technology for Technological Development of the Banderas Bay Region and Social Responsibility, Sustainability and Integral Development for SMEs.

For the development of this project a questionnaire was designed on a web-mobile platform, the Skandia Navigator was used as a measuring instrument, as it is a model that establishes precise indicators to assess each of the components of Intellectual Capital.

\section{Literary review}

\section{Intellectual capital}

Edvinsson and Malone (1999) define Intellectual Capital as the possession of knowledge, applied experience, organizational technology, customer relations and professional skills that give a company a competitive advantage in the market. Therefore, it can be said that Intellectual Capital is an intangible resource owned by companies, which if managed correctly can represent a competitive advantage of the MSMEs that could reverse the statistics of its failure and make it a determining factor for its development.

With regard to the main dimensions or elements of the Intellectual Capital Edvinsson and Malone (1999), they refer to Structural, Relational and Human. 
Structural Capital refers to organizational technology, intellectual property, innovation capacity, organizational culture and policies, formal and informal planning and control systems, trademarks, patents, among others (Ordoñez, 2004).

Relational Capital assumes that companies are systems that are related to their outside, therefore, they are considered relationships with their environment, employees, customers, suppliers, shareholders, administrators, government agencies, competition and society in general. Archibold (2015), comments that Relational Capital represents the added value generated by the organization as an agent that is constantly linked to the surrounding environment, as a result of the correlation between it and the other external factors that interact with it.

Human capital. It refers to the intangible assets that belong to the people who work in the company, such as: professional skills, experience, creativity, knowledge, skill, training, judgment, intelligence, commitment, ability to solve problems and make decisions, talents and motivation. (Ordoñez, 2004).

\section{Skandia Navigator Model}

It is an instrument that measures intellectual capital through financial and non-financial indicators through a visual metaphor to a house (symbol of strength and union), which is explained as follows:

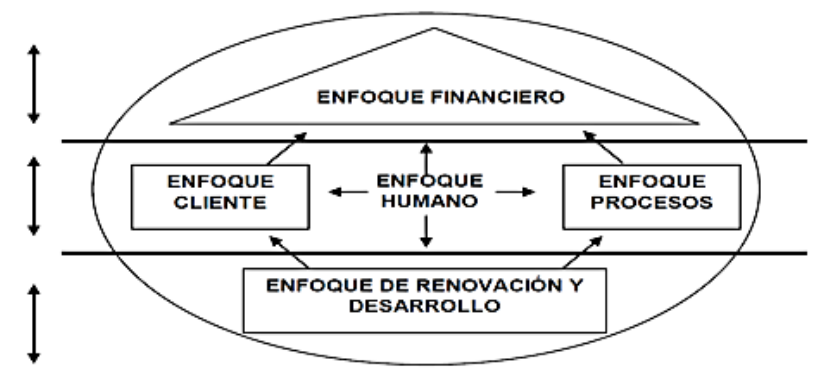

Figure 1 Skandia model

Source: (Edvinsson \& Malone, 1999)

The ceiling is the financial approach that refers to the company's past.
The indicators of this approach are mostly determined by data contained in the financial information; the walls of the house are the clientele approach and the process approach, they mean the present and the activities of the company that are oriented in Intellectual Capital; the base of the house, look to the future, this is the focus of renovation and development and in the center, there is the human approach, which represents the heart, intelligence and soul of the organization, it is the only force that is related to all other approaches to intellectual capital (Edvinsson \& Malone, 1999). The Skandia model establishes different indicators to determine the Intellectual Capital of the companies that translates into an intangible value added and determinant for its development, for this study the last taxonomy of intellectual capital developed by the researchers Göran and Johan Roos was considered (Edvinsson \& Malone, 1999):

\section{Financial approach}

Proposes 18 indicators that identify the most valuable assets of the company at a given date.

1. Total assets $(\$)$.

2. Total assets / employee (\$).

3. Total income / assets (\%).

4. Total benefits / assets (\$).

5. Revenue from new businesses (\$).

6. Benefits from new businesses $(\$)$.

7. Income / Employee (\$).

8. Customer time / employee attention (\%).

9. Benefits / Employee (\$).

10. Benefits from new customers / total revenue $(\%)$.

11. Commercial revenue lost compared to market average $(\%)$.

12. Market Value (\$).

13. Return on net asset value (\%).

14. Return on net assets resulting from operations of a new business (\$).

AGUILAR-MAYA, Laura, GARCÍA-GUERRERO, Martha Gabriela, LÓPEZ-LAGUNA, Ana Bertha, ÁVILA-HERNÁNDEZ, José César and HERNÁNDEZ-CHÁVEZ, Araceli. Intellectual capital of the MSMES in the area of influence. Universidad Tecnológica de Tula Tepeji. RINOE Journal-General Economics. 2019 
15. Value added / employee (\$).

16. Added value / IT-employee (\$).

17. IT investments (\$).

18. Added value / customer (\$).

\section{Customer Focus}

Formula 20 indicators that capture the relationships between the company and its current and potential customers.

1. Market share (\%).

2. Number of customers (\#).

3. Annual sales / customer (\$).

4. Lost Customers (\#).

5. Average duration of relationship with the customer (\#).

6. Average customer size (\$).

7. Customer Rating (\%).

8. Customer visits to the company (\#).

9. Days dedicated to visiting customers (\#).

10. Customers / employees (\$).

11. Sellers on the ground (\#).

12. Managers on the ground (\#).

13. Average time between customer contact and sale (\#).

14. Proportion of contacts to sell regarding closed sales $(\%)$.

15. Customer Satisfaction Index (\%).

16. IT investment / seller (\$).

17. Investment in IT / service and support employee (\$).

18. Support Expense (\$).

19. Service expense / customer / year (\$).

20. Service / customer / contact expense (\$).

ISSN-On line: 2524-2008

RINOE $^{\circledR}$ All rights reserved.

\section{Process approach}

Consider 19 indicators that give us a parameter of the use of technology as a tool to sustain the company and create value, serving as support for human capital so that it can improve its performance.

1. Administration expenses / total income (\#).

2. Cost of administrative errors / sales (\%).

3. Processing time, disbursements (\#).

4. Contracts registered without errors (\#).

5. Function points / employee- month (\#).

6. Personal computers / employee (\#).

7. Laptops / Employee (\#).

8. Administrative / employee expense (\$).

9. Spending on Information Technology / Employee (\$).

10. Computer Technology Expenditure / Administrative Expense (\%).

11. Administrative expense / total premiums $(\%)$.

12. Computer Technology Capability (\#).

13. Variation in IT inventory (\$).

14. Business Quality Goal (\#).

15. Goal performance / business quality (\%).

16. Inventory of Computer Technology Interrupted / Inventory of Computer Technology (\%).

17. Orphan Computer Technology Inventory / Computer Technology Inventory (\%).

18. Information Technology / Employee Capacity (\#).

19. Information Technology / Employee Performance (\#).

AGUILAR-MAYA, Laura, GARCÍA-GUERRERO, Martha Gabriela, LÓPEZ-LAGUNA, Ana Bertha, ÁVILA-HERNÁNDEZ, José César and HERNÁNDEZ-CHÁVEZ, Araceli. Intellectual capital of the MSMES in the area of influence. Universidad Tecnológica de Tula Tepeji. RINOE Journal-General Economics. 2019 


\section{Renewal and development approach}

There are 32 indicators that try to capture the opportunities that define the future of the company. These mainly refer to customers (changes, habits, etc.), in the attractiveness of the market (investment in research, percentage dedicated to current markets, etc.), in products and services (new, product life, etc.), in strategic partners (investments in their development and communication, etc.), in infrastructure (acquisitions, etc.) and in employees (level of training, goals, etc.).

1. Skills development / employee expenditure (\$).

2. Index of satisfied employees (\#).

3. Marketing / customer spending (\$).

4. Participation in training hours (\%).

5. Participation in development hours (\%).

6. Participation in hours of opportunities (\%).

7. Research and Development Expenditure / administrative expenditure (\%).

8. Training / employee expenditure (\$).

9. Training expenditure / administrative expenditure (\%).

10. Business development expenses / administrative expense (\%).

11. Proportion of employees under 40 years $(\%)$.

12. Spending on Information Technology for development / spending on Information Technology (\%).

13. Spending on Information Technology for training / spending on Information Technology (\%).

14. Research resources / total resources (\%).

15. Customer base opportunity captured (\#).

16. Average customer age (\#).

17. Average customer duration with the company, months (\#).

ISSN-On line: 2524-2008

$\mathrm{RINOE}^{\circledR}$ All rights reserved.
18. Investment in education / client (\$).

19. Direct communication with customers / year (\#).

20. Expenses not related to product / customer / year $(\$)$.

21. Investment in development of new markets (\$).

22. Investment in structural capital development (\$).

23. Value of the electronic data exchange (UED) system (\$).

24. Update of the electronic data exchange (UED) system (\$).

25. Training of the electronic data exchange (UED) system (\$).

26. Proportion of new products (less than 2 years old) with respect to the total family of products of the company (\%).

27. Research and development invested in basic research (\%).

28. Research and development invested in product design (\%).

29. Research and development invested in applications (\%).

30. Investments in support and training for new products $(\$)$.

31. Average age of company patents (\#).

32. Patents pending (\#).

\section{Human focus}

It proposes 22 indicators to measure the abilities of the employees, the level of motivation, leadership, sense of belonging, and their contributions to the company.

1. Leadership Index (\%).

2. Motivation Index (\%).

AGUILAR-MAYA, Laura, GARCÍA-GUERRERO, Martha Gabriela, LÓPEZ-LAGUNA, Ana Bertha, ÁVILA-HERNÁNDEZ, José César and HERNÁNDEZ-CHÁVEZ, Araceli. Intellectual capital of the MSMES in the area of influence. Universidad Tecnológica de Tula Tepeji. RINOE Journal-General Economics. 2019 
3. Index of employees with responsibilities (\#).

4. Number of employees (\#).

5. Employee turnover (\%).

6. Average years of service in the company (\#).

7. Number of managers (\#).

8. Number of women managers (\#).

9. Average age of employees (\#).

10. Training time (days / year) (\#).

11. Staff competency in Information Technology (\#).

12. Number of full-time employees / number of permanent employees (\#).

13. Average age of full-time employees / permanent employees (\#).

14. Average years with the company, of permanent full-time employees (\#).

15. Annual rotation of permanent full-time employees (\#).

16. Annual cost per capita of training, communication and support programs for permanent full-time employees (\$).

17. Permanent full-time employee who spend less than $50 \%$ of working hours in a company facility; \% of permanent full-time employees; Annual cost per capita of training, communication and support programs.

18. Number of full-time temporary employees; Average years in the company, of full-time temporary employees.

19. Annual cost per capita of training and support programs for full-time temporary employees $(\$)$.

20. Number of part-time employees / non-fulltime employees (\#).

21. Average contract duration (\#).
22. Percentage of managers who have a higher degree:

- In business sciences (\%)

- In engineering sciences (\%)

\section{Organizational Intellectual Capital Formula}

Edvinsson and Malone propose an equation to calculate intellectual capital:

Organizational Intellectual Capital $=\mathrm{i} C$

$$
\mathrm{i}=(\mathrm{n} / \mathrm{x})
$$

Where:

$\mathrm{C}$ : is the value of intellectual capital in monetary units.

I: is the efficiency coefficient with which Intellectual capital is used.

$\mathrm{n}$ : is equal to the sum of the decimal values of the efficiency indices proposed by these authors.

$\mathrm{x}$ : is the number of those indices.

\section{Methodology}

The type of research was exploratory, crosssectional and with a mixed approach, the survey technique was applied by applying a questionnaire to $32 \mathrm{MSMEs}$ of the Tula-Tepeji area, whose turns are accounting offices; cooperatives for transport of materials, maintenance and cleaning services and extraction of materials for the manufacture of cement; workshops that manufacture parts for engines; lathes; miscellaneous; restaurants; urban transport companies and executive personnel; construction companies; Hotels and hardware stores.

The questionnaire was designed to obtain the necessary information to determine the indicators of the Skandia Navigator Model based on the latest Intellectual Capital taxonomy developed by researchers Göran and Johan Roos (Edvinsson \& Malone, 1999) in a Web-mobile application. 


\section{Results}

As a result of the investigation, the following diagnosis was obtained on the measurement and determination of Intellectual Capital based on the Skandia Navigator Model of the 32 MSMEs of the area of influence of the Technological University of Tula Tepeji:

Financial approach $91 \%$ of MSMEs do not have a plan where objectives and goals are established in the short, medium or long term. They have not implemented a reliable administrative or information system to determine the indicators of this approach. They hire independent professionals who limit themselves to the determination and payment of taxes without keeping a structured accounting that provides reliable and truthful financial information to measure their results. They also have problems in obtaining external financing because they do not generate financial information to support the profitability, liquidity and economic viability of the company; they do not delimit personal finances with those of the business which affects the veracity of the operational results and leads to decapitalization and bankruptcy. The use of business credit is a determining factor to grow the MSMEs, so it is necessary to hire expert advisors to guide and assist in the proper administration of the business.

Customer Focus MSMEs are focused on sales; however, 94\% do not have reliable and accurate information about the market in which they operate; They do not conduct an analysis of the behavior, preferences or degree of satisfaction of their clients, they have not accurately segmented the target client and do not know how their competition behaves. In general, they also do not use ICTs as a means of sale or tool to take a direction and establish strategic plans in the company.

Process approach Entrepreneurs believe that a marketing plan is very expensive, they are unaware that through a good sales campaign you can get new customers. Only $10 \%$ of businesses have a digital presence through social networks or their own website to offer their products.
Renewal and development approach. None of the MSMEs studied have or have registered a patent or have developed new products or services, do not have a research department or train their staff to promote structural capital.

Human focus. $100 \%$ of companies are family, $84 \%$ of owners have no studies on business or business. $87 \%$ do not have their workers and employees insured, have a very high turnover and do not have a work team committed to business objectives.

\section{Conclusion}

In the framework of the previous results, the MSMEs surveyed do not have financial information or administrative procedures to determine the five approaches of the Skandia Navigator, the most important thing for them is to sell but they do not carry out market studies, very few are directed by a professional who apply strategic planning, do not have a defined mission or vision; Likewise, managers do not know what Intellectual Capital is, they do not give importance to staff development and training, they do not use ICTs as a management tool, they do not evaluate processes, nor do they apply continuous improvement; It should be noted that three MSMEs refused to provide information because they considered it confidential.

Finally, it was concluded that the MSMEs in the area of influence of the Technological University have an area of opportunity to develop their intellectual capital, therefore, higher education institutions must contribute to the training of entrepreneurs and design a model for implement appropriate methodologies and procedures that promote Intellectual Capital.

\section{References}

Aguilera, L., Hernández, O., \& Colin, M. (2014). La Relación entre el Capital Intelectual y los procesos de producción en la pyme manufacturera. Cuadernos del CIMBAGE, 87109.

Arango, M., Pérez, G., \& Gil, H. (2007). Propuesta de modelos de gestión de capital intelectual: una revisión. Contaduría Universidad de Antioquia, 105-129. 
Archibold, W., \& Escobar, A. (2015). Capital intelectual y gestión del conocimiento en las contralorías territoriales del departamento del Atlantico. Dimensión Empresarial, 133-146.

Correa, F., Leiva, V., \& Stumpo, G. (2018). Mypymes en América Latina: un frágil desempeño y nuevos desafios para las políticas de fomento. Obtenido de Publicaciones de las Naciones Unidas: https://repositorio.cepal.org/bitstream/handle/11 362/44148/1/S1800707_es.pdf

Edvinsson, L., \& Malone, M. (1999). El Capital Intelectual. Cómo Identificar y calcular el valor de los recursos intangibles de su empresa. México: Gestión 2000.

González, J. (2009). El Capital Intelectual y sus indicadores en el sector industrial. TEACS, 9-33.

Hernández, R. (2002). Activos intangibles. Utilización de enfoques para su medición. La Habana, Cuba: Ibergecyt.

INEGI. (2018). Esperanza de vida de los negocios en México. Obtenido de Esperanza de vida de los negocios en México: https://www.inegi.org.mx/temas/evnm/

Joya, R., Gámez, L., Ortiz, M., \& Gálvez, A. (15 de Mayo de 2015). Medición del Capital Intelectual en empresas mexicanas. Obtenido de Roberto Joya Arreola Centro universitario de la costa Sur, Universidad de Guadalajara: http//scielo.sld.sid.cu/scielo.php?script=sci_artt ext\&pid=S2306-91552015000100004

Manene, L. (2 de Septiembre de 2010). La gestión del Conocimiento y el Capital Intelectual. Obtenido de Blog de Luis Manuel Manene:

https://luismiguelmanene.wordpress.com/2010/ 09/02/la-gestion-del-conocimiento-y-el-capitalintelectual-2/

Méndez, F. (2007). Propuesta de un modelo para desarrolar el capital Intelectual en las Microempresas de México. México: Instituto Politecnico Nacional.

Monagas, M. (2012). El Capital intelectual y la gestión del conocimiento. Ingenieria industrial, 142-150.
Moreno, L., \& Peña, C. (2007). Universidad de San Buena Ventura. Obtenido de Facultdad de Ciencias Empresariales, Bogota: http://biblioteca.usbbog.edu.co:8080/Biblioteca/ BDigital/40688.pdf

Ordoñez, P. (2004). Revista Economía Industrial. Las cuentas de capital intelctual como complemento del informe anual, 63-74. Obtenido de http://www.minetur.gob.es/Publicaciones/Publi cacionesperiodicas/EconomiaIndustrial/Revista EconomiaIndustrial/357/07_PatriciaOrdonez_3 57.pdf

Osorio, M. (27 de septiembre de 2003). El Capital intelectual en la gestión del conocimiento. Habana, Cuba. Obtenido de http://bvs.sld.cu/revistas/aci/vol11_6_03/aci076 03.htm

Perón, H. (noviembre de 2012). Las Pymes, actores en la escena económica. Obtenido de $\mathrm{http}: / /$ www.monografias.com/trabajospdf5/pymes-actores-escenario-economicovacunas-mortalidad-pymes/pymes-actoresescenario-economico-vacunas-mortalidadpymes.shtml

Rangel, J., Aguilera, L., \& González, M. (2013). La innovación y el capital intelectual: factores de competitividad en la pyme manufacturera. Mercados y negocios, 151-168.

Rodríguez, A. (junio de 2012). ¿qué es la economía del conocimiento? Observatorio Académico Universitario. Obtenido de Instituto Tecnologico de Tijuana: http://redacademica.net/observatorio-

academico/2012/06/15/que-es-la-economia-delconocimiento/

Sanchez, A., Hormiga, E., \& Melián, A. (2007). El concepto de Capital Intelectual y sus dimensiones. Investigaciones Europeas de Dirección y Economía de la Empresa, 97-111.

Sánchez, J. (2013). Factores de éxito de la micro, pequeña y mediana empresa en edad. Obtenido de http://www.chi.itesm.mx/investigacion/wpcontent/uploads/2013/11/NEG30.pdf 
Soriano, C. (noviembre de 2005). Por qué fracazan las Pymes. Obtenido de http://www.gestiopolis.com/por-que-fracasanlas-pymes/

Ugalde, N. (2011). Capital Intelectual e Innovación: Una sinergía necesaria. Ciencias Económicas, 463-474. 